\title{
Pendidikan Kewirausahaan dalam Islam
}

\section{Fikri Maulana}

Pascasarjana Institut PTIQ Jakarta, Indonesia

fikrimevlana24@gmail.com

\begin{abstract}
Abstrak:
Penelitian ini merupakan kajian pustaka (library research) dan dengan metode tafsir tematik. Metode tafsir digunakan untuk membedah ayat-ayat yang berkenaan dengan motivasi wirausaha. Setelah melakukan kajian tentang motivasi wirausaha dalam Islam yakni dalam Alquran dan Hadis, ditemukan beberapa hal sebagai berikut: (1) Pandangan Alquran tentang motivasi wirausaha dapat ditemukan pada teks Alquran surat al-Jumuah ayat 10, ash-Shaf ayat 10-11 dan al-Qashash ayat 77. (2) Pandangan hadis tentang motivasi wirausaha dapat ditemukan pada teks hadis yang diriwayatkan oleh Imam al-Bukhari yang bersumber dari Miqdam Ibnu Ma'dikarib ra. dan diriwayatkan oleh Ibnu Asakir yang bersumber dari anas ra. (3) Pandangan tentang motivasi seorang wirausaha yakni perintah untuk bertebaran di muka bumi bukan diam di tempat, kemudian perintah mencari karunia Allah dan banyak mengingatlah Allah. Selain itu, seorang wirausaha dituntut untuk saling membantu atau tolong menolong dalam kebaikan dan tidak memperkaya diri agar seimbang kebutuhan antara dunia dan akhirat.
\end{abstract}

Kata Kunci: Motivasi, Wirausaha, Islam

\begin{abstract}
:
This research is a literature study (library research) and with a thematic interpretation method. The interpretation method is used to dissect the verses relating to entrepreneurial motivation. After conducting a study of entrepreneurial motivation in Islam, namely in the Koran and Hadith, found several things as follows: (1) Alquran's view of entrepreneurial motivation can be found in Surah al-Jumuah verse 10, ash-Shaf verses 10-11 and al-Qashash verse 77. (2) The view of the hadith about entrepreneurial motivation can be found in the hadith text narrated by Imam al-Bukhari sourced from Miqdam Ibn Ma'dikarib ra. and narrated by Ibn Asakir who sourced from ra. (3) The view of the motivation of an entrepreneur is the command to scatter
\end{abstract}


on earth rather than stay in place, then the command to seek the gift of God and remember God a lot. In addition, an entrepreneur is required to help each other or help in goodness and not enrich themselves so as to balance the needs of the world and the hereafter.Abstracts and keywords written in two languages (Indonesian and English). The length of each abstract is 200-250 words, instead of keywords 3-5 words count. Abstracts contain minimal problems, objectives, methods, concepts, and results of research and discussion

Keywords: Motivation, Entrepreneurship, Islam

\section{Pendahuluan}

Islam mengarahkan manusia untuk menjalani kehidupannya melalui Alquran yang berfungsi sebagai petunjuk bagi manusia (hudan linnas) dan petunjuk bagi orang yang bertakwa (hudan lil muttaqin). Selain itu, terdapat sunnah Nabi Muhammad Saw yang patut dijadikan teladan bagi umatnya untuk melewati hari-hari dengan akhlak terpuji. Dalam Alquran surat alJumuah ayat 9 dijelaskan bahwa bertebaranlah di muka bumi untuk mencari anugerah Allah Swt. Ayat tersebut mengisyaratkan bahwa manusia harus berusaha dan jangan malas dalam mencari anugerah Allah Swt. Ayat tersebut juga mengisyaratkan bahwa dalam agama Islam dilarang bermalas-malas dan hanya meminta-minta kepada manusia, sejatinya meminta hanya kepada Allah Swt melalui beriman dan beramal shalih.

Demikian juga dengan kekhawatiran Nabi Muhammad Saw dalam sebuah hadis beliau bersabda kaadal faqru ayyakunal kufro, yang artinya hampir saja kefaqiran menyebabkan kekufuran. Dari hadis ini nabi Muhammad Saw menginginkan umatnya sejahtera secara ekonomi agar terhindar dari kekufuran. Sebabnya, tidak sedikit masalah ekonomi dapat mengakibatkan manusia tidak bersyukur atas nikmat Allah Swt yang telah diterimanya.

Berdasarkan survei nasional menunjukan bahwa sebagian dari 10.000 peserta didik SMA mengaku pernah mencuri di pertokoan. ${ }^{1}$ Dengan demikian, kemiskinan masih menjadi permasalahan di Indonesia. Kemiskinan terjadi karena perbandingan antara jumlah penawaran kesempatan kerja tidak sebanding dengan jumlah lulusan atau penawaran tenaga kerja baru di segala level pendidikan. ${ }^{2}$

Jika ditarik ke sejarah, bangsa Indonesia sudah mengenal konsep ekonomi kesejahteraan rakyat, sebagaimana yang dilakukan oleh Hadratusyaikh Hasyim Asy'ari dari Jombang Jawa Timur, bahwasanya pada tahun 1919, ketika booming informasi dan wacana tentang koperasi sebagai bentuk kerjasama ekonomi di tengah-tengah masyarakat, maka

\footnotetext{
${ }^{1}$ Michele Berba, Membangun Kecerdasan Moral (Jakarta: Gramedia Pustaka Utama, 2008).

${ }^{2}$ Leonardus Saiman, Kewirausahaan: Teori, Praktik, dan Kasus-Kasus (Jakarta: Penerbit Salemba Empat, 2009).
} 
Hadratusyaikh Hasyim Asy'ari tampil degan gagasan briliannya, sehingga terbentuklah sebuah badan semacam koperasi yang disebut Syirkatul Inan Li Murabathati Ahli al-Tujjar. Di badan ini umat muslim terpancing untuk meningkatkan kesejahteraan hidup dan memulai hidup baru dengan spirit baru. ${ }^{3}$

Lebih jauh lagi, sejarah Islam merekam jejak perjalanan hidup yang agung dari Nabi Muhammad SAW dan dalam sejarah kehidupan beliau, sangat kental dengan nilai-nilai pendidikan kewirausahaan yang sangat layak menjadi panduan. Sehingga pada abad ke-13 pedagang muslim menyebarkan Islam ke seluruh penjuru dunia sambal berdagang. ${ }^{4}$

Namun, pada kenyataannya berwirausaha kadang-kadang mengalami kerugian bahkan kegagalan. Dengan demikian, dibutuhkan motivasi untuk membangkitkan semangat dan memperbaiki niat seorang wirausaha dalam menjalankan aktivitas wirausahanya. Dengan motivasi yang kuat dan niat baik yang tertanam dalam diri seorang wirausha, maka aktivitas wirausaha yang dijalankan bukan hanya mendapatkan keuntungan, akan tetapi memilki nilai ibadah disisi Allah Swt.

Namun, umat Islam Indonesia sepertinya tidak begitu tertarik dengan berwirausaha. Tidak sedikit yang lebih condong menjadi pegawai. Akibatnya, sebagai umat mayoritas, umat Islam Indonesia jauh tertinggal dari umat lain. Padahal, menurut McClelland jika suatu negara ingin makmur harus memiliki 2 persen dari jumlah penduduk. Bahkan Singapura memiliki 2,7 persen entrepreneur dari jumlah warga negaranya. survei tersebut dilakukan pada tahun $2005^{5}$. Berdasarkan survei, Indonesia hanya memiliki 0,18 persen entrepreneur dari 220 juta jumlah penduduk, jika dari survei tersebut ditelisik lebih jauh lagi, jumlah entrepreneur yang hanya 2 persen tersebut secara umum, jumlah entrepreneur yang beragama Islam atau entrepreneur muslim secara khusus jauh lebih sedikit, padahal seharusnya sudah saatnya bermunculan generasi entrepreneur dari kalangan kaum muslim.

Dengan demikian, setiap individu umat Islam harus mulai berpikir dan berinteraksi dengan individu atau kelompok untuk berwirausaha dan menjalin kerjasama dalam bentuk kemitraan maupun persaingan. Dengan kata lain, wirausaha penting untuk dilakukan oleh setiap individu umat Islam. Sebagaimana Nabi Muhammad SAW bersabda,

Tiada seorang yang makan makanan yang lebih baik dari makanan dari hasil usahanya sendiri (wirausaha). Sesunggunya Nabi Allah Daud, itupun makan dari hasil usahanya sendiri (wirausaha). (H.R. Bukhari)

\section{Wirausaha dalam Alquran dan Hadis}

\footnotetext{
${ }^{3}$ Aguk Irawan, Penakluk Badai (Jakarta: Republika, 2012).

${ }^{4}$ Muhammad Anwar, Pengantar Kewirausahaan, Teori dan Aplikasi (Jakarta: Prenada, 2014).

${ }^{5}$ Ciputra, Quantum Leap Entrepreneurship (Jakarta: Elex Media Komputindo, 2009).
} 
Kata wirausaha merupakan serapan dari bahasa Prancis, yakni entrepreneur. Kata ini pertama kali dikenalkan oleh Richard Cantillon pada abad ke-18 Masehi. Adapun dalam bahasa Indonesia kata entrepreneur diterjemahkan menjadi wirausaha, yang mana wirausaha merupakan gabungan dari kata wira dan usaha, wira artinya teladan atau contoh sedangkan usaha artinya kemauan keras untuk memperoleh manfaat. ${ }^{6}$ Sehingga menurut Tarsis Turmuji wirausaha adalah seseorang yang berkemauan keras dalam bisnis yang patut menjadi contoh. ${ }^{7}$ Adapun menurut Kasmir, secara sederhana arti wirausahawan (entrepreneur) adalah orang yang berjiwa berani mengambil resiko untuk membuka usaha dalam berbagai kesempatan berjiwa berani mengambil resiko artinya bermental mandiri dan berani memulai usaha, tanpa diliputi rasa takut atau cemas sekalipun dalam kondisi tidak pasti. ${ }^{8}$ Sedangkan menurut Machfoedz, seorang wirausahawan adalah pribadi yang mandiri dalam mengejar prestasi, ia berani mengambil resiko untuk mulai mengelola bisnis demi mendapatkan laba. ${ }^{9}$

Tidak berbeda jauh dengan pendapat di atas, menurut Buchari Alma, seorang wirausaha adalah orang yang melihat adanya peluang kemudian menciptakan sebuah organisasi untuk memanfaatkan peluang tersebut. ${ }^{10}$ Dengan demikian, dari pandangan para ahli diatas terkait wirausaha, maka dapat disimpulkan bahwa wirausaha memiliki 3 kata kunci yakni orang yang dapat melihat dan memanfaatkan peluang, orang yang berjiwa berani dalam mengambil resiko dalam menjalankan usahanya dan mandiri dalam mengejar prestasi sehingga patut dicontoh.

Dalam Alquran surat al-Jumuah ayat 10, Allah Swt memerintahkan umat Islam untuk tidak bermalas-malasan setelah menjalankan Ibadah, akan tetapi dibertebaran di muka bumi dan melakukan aktivitas pencarian anugerah Allah Swt, yang berbunyi:

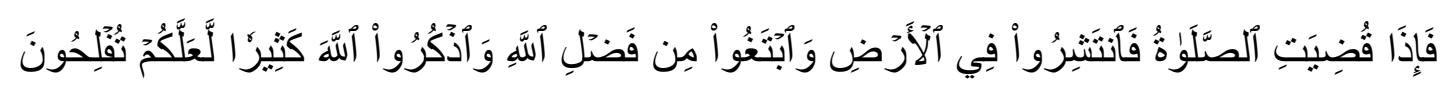
Apabila telah ditunaikan shalat, maka bertebaranlah kamu di muka bumi; dan carilah karunia Allah dan ingatlah Allah banyak-banyak supaya kamu beruntung.

Ayat tersebut menyatakan apabila telah ditunaikan sholat, maka bertebaranlah dimuka bumi dan carilah sebagian dari karunia Allah dan ingatlah Allah banyak-banyak supaya kamu beruntung. ${ }^{11}$ Kata bertebaranlah dan carilah sebagian dari karunia Allah serta ingatlah Allah banyak-banyak merupakan prinsip wirausaha.

\footnotetext{
${ }^{6}$ M. Ma'ruf Abdullah, Wirausaha Berbasis Syariah (Yogyakarta: CV. Aswaja Pressindo, 2011).

${ }^{7}$ Tarsis Tarmudji, Prinsip-Prinsip Wirausaha (Yogyakarta: Liberty, 2003).

${ }^{8}$ Kasmir, Kewirausahaan (Jakarta: PT Raja Grafindo Persada, 2008)

${ }^{9}$ Mahmud Mahfoedz, Kewirausahaan, Metode, Manajemen dan Implementasi (Yogyakarta: BPFE, 2006).

${ }^{10}$ Buchari Alma, Manajemen Bisnis Syariah (Bandung: Alfabeta, 2009).

${ }^{11}$ Quraish Shihab, Tafsir Al-Misbah Juz 4 (Jakarta: Lentera Hati. 2002).
} 
Quraish Shihab menyatakan bahwa kata wirausaha mempunyai banyak padanan kata. Dalam bahasa Inggris sering dipadankan dengan kata buyying and selling, commerce, trade yang bermakna jual beli, perniagaan atau perdagangan. Pada intinya, wirausaha atau bisnis adalah interaksi antara dua pihak dalam bentuk tertentu guna meraih manfaat. Namun dalam interaksi tersebut dibutuhkan menejemen yang baik untuk memperkecil kemungkinan risiko yang akan muncul. Dan menurut Quraish Shihab dalam bahasa Arab interaksi seperti itu disebut dengan istilah muamalah, yang dalam kajian fiqh Islam disebut dengan fiqh muamalah. ${ }^{12}$

Lebih lanjut, Quraish Shihab memaparkan bahwa seorang pengusaha harus mempunyai niat yang baik. Usaha atau bisnis tidak hanya sekedar mengejar keuntungan semata. Tidak juga hanya untuk memperkaya diri, tapi usaha yang kita rintis harus menjadi sarana untuk saling membantu dalam memenuhi kebutuhan orang lain. Dan pada akhirnya, bisnis yang demikian itu, akan bernilai ibadah bahkan sebagian daripada jihad. ${ }^{13}$

Sebagaimana dalam Alquran surat al-Maidah ayat 3, yang berbunyi:

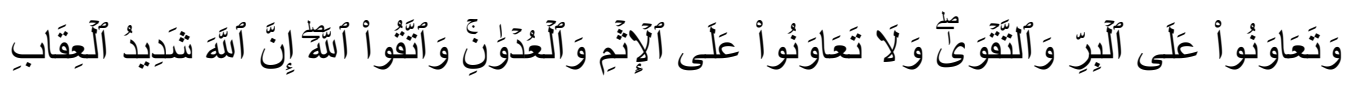

Dan tolong-menolonglah kamu dalam (mengerjakan) kebajikan dan takwa, dan jangan tolong-menolong dalam berbuat dosa dan pelanggaran. Dan bertakwalah kamu kepada Allah, sesungguhnya Allah amat berat siksa-Nya.

Dalam Alquran ada terdapat pula ayat yang menunjukkan istilah wirausaha atau dagang, yakni dengan padanan kata bay'i dan tijarat. Sebagaimana dalam surat ash-Shaf ayat 10-11, yang berbunyi:

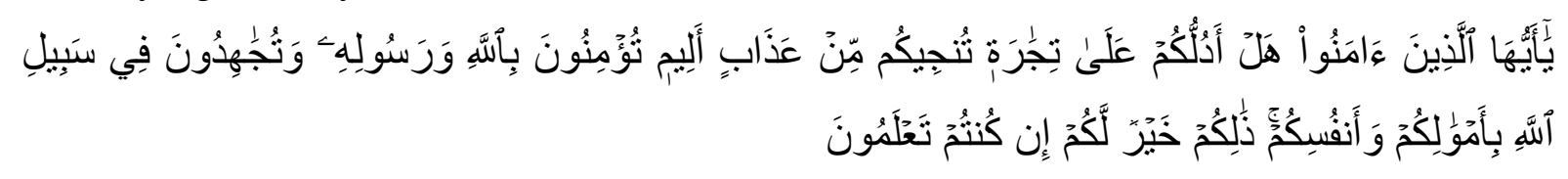

Hai orang-orang yang beriman, sukakah kamu aku tunjukkan suatu perniagaan yang dapat menyelamatkanmu dari azab yang pedih? (yaitu) kamu beriman kepada Allah dan Rasul-Nya dan berjihad di jalan Allah dengan harta dan jiwamu. Itulah yang lebih baik bagimu, jika kamu mengetahui.

Menurut Zenrif memaparkan bahwa konsep bisnis dalam Alquran dapat dipadankan dengan kata bay'i dan tijarah, yang berarti memberikan sesuatu kepada seseorang dengan mengambil harga darinya. Orang yang memberikan disebut bay' $i$ atau penjual sedangkan barang yang diberikannya disebut mabi' atau pembeli. ${ }^{14}$ Dengan demikian, kata bay'i berkonotasi makna sosial, persahabatan yang dibangun di atas pondasi kasih sayang dan bahkan pertolongan. Makna lebih luasnya dengan perdagangan dapat membangun silaturrahmi

\footnotetext{
12 Quraish Shihab, Berbisnis Dengan Allah (Jakarta: Lentera Hati, 2008).

${ }^{13}$ Quraish Shihab, Berbisnis Dengan Allah (Jakarta: Lentera Hati, 2008).

${ }^{14}$ Louis Ma'luf, Al-Munjid (Beirut: Dar al-Masyriq, 1987).
} 
antara sesama manusia, saling membantu memenuhi kebutuhan masing-masing dan tentu saling mendapatkan keuntungan (antaradhim minhum). Sedangkan, kata kedua yang menunjukkan pada usaha dan bisnis adalah tijarat. Secara leksikal, tijarat berasal dari kata tajara, tajran wa tijaratan yang bermakna jual beli yang bertujuan mendapatkan keuntungan. Sementara Imam Hanafi menyatakan bahwa bay'i adalah pertukaran harta dengan harta dengan cara khusus, atau pertukaran barang yang dibutuhkan dengan cara tertentu, yakni dengan penerimaan dan pemberian. Hampir senada dengan Imam Nawawi yang mendefinisikan sebagai sebuah kegiatan pertukaran harta milik seseorang dengan harta milik orang lain. ${ }^{15}$

Semetara itu, lebih lanjut Jusmaliani dalam bukunya Bisnis Berbasis Syariah menyatakan bahwa dagang atau perdagangan sebagai konsep sangat penting dalam Islam. Di antara bukti pentingnya konsep tersebut yakni ketika Alquran memakai istilah tersebut yang multimakna. Kata perdagangan tidak hanya digunakan untuk menunjuk pada aktivitas transaksi dalam pertukaran barang atau produk tertentu pada kehidupan nyata dalam sehari-hari, tapi juga ditunjukkan pada sikap ketataan seseorang pada Allah Swt. Dalam arti lain bahwa perdagangan mencakup pengertian eskatalogis, yaitu dagang yang bersifat ibadah. ${ }^{16}$

Dengan demikian, wirausaha dalam Alquran dapat diartikan perdagangan yang memiliki makna ibadah dan tidak memmperkaya diri. Lebih lanjut, seorang wirausaha seharusnyaa memiliki prinsip hidup yang mandiri tidak bermalas-malas berada di suatu tempat yang nyaman dan senantiasa berusaha mencari karunia Allah dengan cara yang halal dan baik serta tidak lupa berdzikir kepada Allah yang telah memberikan kepadanya nikmat yang banyak. Sedangkan dalam Hadis Nabi Saw. dari Muadz ra. dijelaskan bahwa:

Termasuk sebaik-baik penghasilan adalah penghasilan para pedagang yang bila berbicara tidak berbohong, bilah diberi kepercayaan tidak mengkhianati, bila berjanji tidak menyalahi, bila membeli tidak mencela, bila menjual tidak meninggikan harga, bila punya tanggungan tidak menunda-nunda, dan bila mempunyai sesuatu tidak mempesulit (HR. Hakim dan Baihaqi)

Selanjutnya, dalam hadis dijelaskan tentang motivasi berwirausaha, Nabi Muhammad Saw sendiri telah menyatakan, bahwa 9 dari 10 pintu rezeki adalah melalui pintu berdagang. Artinya, melalui jalan perdagangan inilah, pintu-pintu rezeki akan dapat dibuka, sehingga karunia Allah Swt terpancar daripadananya. ${ }^{17}$

\section{Pengertian Motivasi dan Kaitannya dengan Wirausaha}

Motivasi berasal dari kata latin movere yang berarti dorongan, daya penggerak atau kekuatan yang menyebabkan suatu tindakan atau perbuatan. Kata movere dalam bahasa inggris,

\footnotetext{
${ }^{15}$ Wahbah Zuhaily, Al-Fiqh al-Islamiy wa Adillatuh Juz IV (Damasyiq: Dar al-Fikr, 1989).

16 Jusmaliani, Bisnis Berbasis Syariah (Jakarta: Bumi Aksara, 2008).

17 Viethzal Rivai, Islamic Business and Economic Ethics (Jakarta: PT Bumi Aksara, 2012).
} 
sering disepadankan dengan motivation yang berarti pemberian motif, penimbulan motif, atau hal yang menimbulkan dorongan atau keadaan yang menimbulkan dorongan.

Motivasi merupakan suatu dorongan yang membuat orang bertindak atau berperilaku dengan cara-cara motivasi yang mengacu pada sebab munculnya sebuah perilaku, seperti faktor-faktor yang mendorong seseorang untuk melakukan atau tidak melakukan sesuatu. Motivasi dapat diartikan sebagai kehendak untuk mencapai status, kekuasaan dan pengakuan yang lebih tinggi bagi setiap individu. Motivasi justru dapat dilihat sebagai basis untuk mencapai sukses pada berbagai segi kehidupan melalui peningkatan kemampuan dan kemauan. ${ }^{18}$

Hamzah menjelaskan istilah motivasi berasal dari kata motif yang dapat diartikan sebagai kekuatan yang terdapat dalam diri individu, yang menyebabkan individu tersebut bertindak atau berbuat. Motif tidak dapat diamati secara langsung, tetapi dapat diinterpretasikan dalam tingkah lakunya, berupa rangsangan dorongan, atau pembangkit tenaga munculnya suatu tingkah laku tertentu. ${ }^{19}$

Oemar Hamalik menjelaskan motivasi dapat berupa dorongan-dorongan dasar atau internal dan intensif diluar individu atau hadiah. Motivasi adalah proses membangkitkan, mempertahankan, dan mengontrol minat-minat. ${ }^{20}$ Sedangkan menurut Winardi menyatakan bahwa motivasi adalah keinginan yang terdapat pada diri seseorang yang merangsangnya untuk melakukan tindakan-tindakan. ${ }^{21}$

Dengan demikian, dari penjelasan para ahli diatas dapat disimpulkan bahwa motivasi motivasi suatu dorongan atau keinginan seseorang didalam melakukan suatu keinginan atau usaha demi tercapainya tujuan yang diinginkan dan memegang peranan penting dalam diri seseorang.

Kebanyakan orang yang berhasil di dunia ini mempunyai motivasi yang kuat yang mendorong tindakan-tindakan mereka. Mereka mengetahui dengan baik yang menjadi motivasinya dan memelihara motivasi tersebut dalam setiap tindakannya. ${ }^{22}$ Motivasi berada dalam diri manusia yang terlihat dari luar. Motivasi merupakan dorongan yang telah telah terikat pada suatu tujuan. Salah satu teori yaitu proses, yang berusaha menjelaskan proses munculnya hasrat seseorang untuk menampilkan tingkah laku tertentu. ${ }^{23}$ Teori ini, mencoba

\footnotetext{
${ }^{18}$ George Terry, Prinsip-Prinsip Manajemen (Jakarta: Bumi Aksara, 1996).

${ }^{19}$ Hamzah B. Uno, Teori Motivasi dan Pengukurannya (Jakarta: Bumi Aksara, 2008).

${ }^{20}$ Oemar Hamalik, Psikologi Belajar dan Mengajar (Bandung: Sinar Baru Algensindo, 2004).

${ }^{21}$ Amri, Proses Pembelajaran Kreatif dan Inovatif dalam Kelas (Jakarta: PT Prestasi Pustakaraya, 2010).

${ }^{22}$ Baum \& Baron, The psychology of entrepreneurship (New Jersey: Lawrence Erlbaum Associates, 2007).

${ }^{23}$ Yunus Suryana dan Kartib Bayu, Kewirausahaan: Pendekatan Karakteristrik Wirausaha Sukses (Jakarta: Kencana, 2011).
} 
untuk menggambarkan proses yang terjadi dalam pikiran seseorang yang akhirnya seseorang itu menampilkan tingkah laku tertentu. Teori ini sebagai berikut:

\section{Equity Theory}

Teori ini, mengindikasikan bahwa pada dasarnya manusia menyenangi perlakuan yang adil. Manusia akan termotivasi kerja dengan baik bilamana diperlakukan secara adil.

2. Expanctancy Theory

Besar kecilnya usaha kerja yang akan diperlihatkan oleh seseorang, tergantung pada bagaimana orang ini memandang kemungkinan berhasil dari tingkah lakunya itu dalam mencapai atau menghindari.

Motivasi memiliki dua fungsi, yaitu pertama mengarahkan atau directional function, dan kedua mengaktifkan dan meningkatkan kegiatan atau activating and energizing function. Dalam mengarahkan kegiatan, motivasi berperan mendekatkan atau menjauhkan individu dari sasaran yang akan dicapai. Apabila sesuatu sasaran atau tujuan merupakan sesuatu yang diinginkan oleh individu, maka motivasi berperan mendekatkan, dan bila sasaran atau tujuan tidak diinginkan oleh individu, maka motivasi berperan menjauhi sasaran. Karena motivasi berkenaan dengan kondisi yang cukup kompleks, maka mungkin pula terjadi bahwa motivasi tersebut sekaligus berperan mendekatkan dan menjauhkan sasaran (approachavoidance motivation). ${ }^{24}$

Berkaitan dengan wirausaha, Bygrafe mengemukakan 10 sifat yang dimiliki oleh wirausaha, yang dikenal dengan istilah $10 \mathrm{D},{ }^{25}$ yaitu:

1. Dream, wirausaha mempunyai visi tentang kenginannya di masa depan dalam kehidupan pribadi dan usahanya dan berusaha untuk menggunakan kemampuannya untuk mewujudkan visi tersebut.

2. Decisivenese, wirausaha tidak bekerja lambat. Keputusan yang diambilnya merupakan keputusan yang cepat namun, tetap penuh perhitungan. Kecepatan dan ketepannya dalam mengambil keputusan merupakan faktor utama dalam kesuksesan bisnis.

3. Doers, setelah keputusan diambil wirausaha langsung mengambil tindakan lebih lanjut. Kegiatannya di lakukan dengan cepat tanpa ditunda.

4. Determination, kegiatan yang dilakukan oleh wirausaha dilakukan dengan penuh perhatian. Ia memiliki sikap tanggung jawab dan tidak menyerah pada halangan apapun.

\footnotetext{
${ }^{24}$ Nana Syaodih Sukmadinata, Landasan Psikologi Proses Pendidikan (Bandung: PT Remaja Rosdakarya, 2007).

${ }^{25}$ Buchari Alma, Manajemen Pemasaran dan Pemasaran Jasa (Bandung: Alfabeta, 2007).
} 
5. Dedication, wirausaha mendedikasikan dirinya pada bisnis yang dijalankan dengan sungguh-sungguh tidak jarang mereka mengorbankan keluarganya dan kesenangan dirinya untuk sementara waktu.

6. Devotion, wirausaha mencintai pekerjaan dan produk yang dihasilkannya. Kecintaannya pada pekerjaan membuat ia terdorong untuk mencapai hasil yang diinginkan.

7. Details, wirausaha memperhatikan segala faktor yang ada tanpa mengabaikan faktor sekecil apapun yang dapat menghambat berjalannya bisnis.

8. Destiny, wirausaha bertanggung jawab pada nasib dan tujuan yang ingin dicapai. Ia menyukai kebebasan tanpa bergantung pada orang lain.

9. Dollars, motivasi wirausaha tidak hanya untuk mendapatkan uang. Melainkan uang digunakan sebagai ukuran kesuksesan yang telah diraihnya. Ia merasa layak untuk mendapatkan keuntungan jika bisnisnya sudah dapat berjalan dengan sukses.

10. Distribute, wirausaha bersedia mendistribusikan kepemilikan bisnisnya pada orang yang telah dipercaya. Orang-orang kepercayaannya merupakan orang yang memiliki semangat dan jalan pikiran yang sama.

David Moors dalam bukunya The Enterprising mengungkapkan bahwa ciri-ciri wirausaha adalah mengenai personality dan pelaku wirausaha itu sendiri, di samping lingkungan yang mendukungnya, juga tugas-tugas yang diemban oleh seorang wirausaha dan karir yang bisa dicapainya.

Lebih lanjut katanya, the act of enterpreneurship is an act patterned after modes of coping with early childhood experiences. Personality atau kepribadian seorang wirausaha adalah sikap yang didapatkannya sejak masa kecil yaitu sikap merdeka, bebas dan percaya diri. ${ }^{26}$ Ketiga sikap ini sangat dipengaruhi oleh lingkungan kedua orang tua di mana peran ibu yang begitu penuh dedikasi terhadap perkembangan anaknya sangat berpengaruh. Pengaruh dari kedua orang tua juga bisa sangat menunjang atau bahkan merusak salah satu atau ketiga unsur kepribadian wirausaha seorang anak.

Terkait dengan konsep di atas, Nabi Muhammad Saw telah menjadi wirausahawan yang memiliki kemerdekaan dan kepercayaan diri yang tinggi. Hal itu terbentuk dari proses dan pengalaman hidup yang ia lalui. Dalam sejarahnya yang agung, beliau lahir seorang yatim dan ditinggal ibunya ketika masih berumur enam tahun. Beliau lantas diasuh oleh kakeknya, Abdul Muttalib. Namun tak lama bersamanya, beliau pun harus berpisah dengan sang kakek di usia 8

26 Thobrani, Super Sukses Muhammad (Yogyakarta: Cakrawala, 2011). 
tahun. Sehingga pada akhirnya, beliau dibesarkan oleh pamannya yakni Abu Thalib sampai beliau dewasa dan menerima amanah kenabian dan kerasulan. ${ }^{27}$

Pada dasarnya, Nabi Muhammad SAW sejak beliau kecil telah mendapatkan julukan di masyarakat kota Makkah sebagai al-Amin (orang yang terpercaya). Padahal beliau pun juga telah memiliki sifat wajib bagi rasul yang melekat yakni, shiddiq, amanah, tabligh, fathanah. Dengan sifat-sifat tersebut, beliau mendapat kepercayaan dari para pemilik modal. Termasuk ketika itu adalah Sayyidah Khadijah sebagai pemegang modal yang memberikan tawaran untuk menjalin mitra kerja sama dalam membangun bisnis yang berdasarkan pada sistem bagi hasil atau mudarabah. ${ }^{28}$

Selanjutnya, setelah beranjak usia remaja Nabi Muhammad SAW mulai dikenal di Syiria, Yaman, Bashrah, Yordania dan kota-kota metropolitan di Jazirah Arabiyah. Dengan semangat suka sama suka (antaradhimminhum) dan kejujuran dan profesionalisme membuatnya beliau semakin disenangi oleh mitra bisninya. Dan secara tidak langsung, beliau pun telah berhasil menanam benih etika dasar dalam wirausaha yang kemudian menjadi refrensi hingga dewasa ini.

\section{Urgensi Motivasi Wirausaha dalam Alquran dan Hadis}

Alma menyatakan terdapat 3 faktor yang berperan dalam motivasi berwirausaha, ${ }^{29}$ yaitu:

1. Personal atau kepribadian, yakni menyangkut aspek-aspek kepribadian seseorang. David Mc Clelland menyatakan bahwa seorang wirausaha adalah seseorang yang yang memiliki keinginan berprestasi yang sangat tinggi dibandingkan orang yang tidak berwirausaha.

2. Sociological atau hubungan sosial, yakni itu menyangkut masalah hubungan dengan family dan hubungan sosial lainya. Alma menyatakan masalah hubungan family ini dapat dilihat dari orang tua, pekerjaan, dan status sosial. Faktor sosial yang berpengaruh terhadap minat berwirausaha ialah masalah tanggung jawab terhadap keluarga.

3. Environmental atau lingkungan, yakni menyangkut hubungan dengan lingkungan. Suryana menyatakan faktor yang berasal dari lingkungan di antaranya adalah model peran, peluang, aktivitas, selain itu dipengaruhi juga oleh pesaing, sumber daya, dan kebijakan pemerintah. ${ }^{30}$

\footnotetext{
${ }^{27}$ Syekh Shafiyyur Rahman al-Mubarakfury, Sirah Nabawiyah (Jakarta: Pustaka al-Kautsar, 2000).

${ }_{28}$ Thobrani, Super Sukses Muhammad (Yogyakarta: Cakrawala, 2011).

${ }^{29}$ Buchari Alma, Manajemen Pemasaran dan Pemasaran Jasa (Bandung: Alfabeta, 2007).

${ }^{30}$ Suryana, Kewirausahaan Pedoman Praktis: Kiat Dan Proses Menuju Sukses (Jakarta: Salemba Empat, 2008).
} 
Dalam Entrepreneur Handbook, dikemukakan beberapa alasan mengapa seseorang berwirausaha, ${ }^{31}$ yaitu:

1. Alasan keuangan, yaitu untuk mencari nafkah, untuk menjadi kaya, untuk mencari pendapatan kekayaan, sebagai stabilitas keuangan.

2. Alasan sosial, yaitu untuk memperoleh gengsi/ status, untuk dapat dikenal dan dihormati.

3. Alasan pelayanan, yaitu untuk memberi pekerjaan pada masyarakat, untuk menatar masyarakat, untuk membantu ekonomi masyarakat, demi masa depan anak-anak dan keluarga, untuk mendapatkan kesetiaan suami/istri, untuk membahagiakan orangtua.

4. Alasan pemenuhan diri, yaitu untuk menjadi mandiri, untuk menjadi sesuatu yang diinginkan, untuk menghindari ketergantungan pada orang lain, untuk menjadi lebih produktif, dan untuk menggunakan kemampuan pribadi.

Dalam Alquran terdapat hal-hal yang menjelaskan tentang entrepreneurship atau wirausaha yang dapat dijadikan dasar dalam memotivasi umat Islam untuk melakukan entrepreneurship atau wirausaha. Sebagaimana perintah Allah Swt untuk menyeimbangkan urusan dunia dan akhirat yang tertuang dalam Alquran surat al-Qashash ayat 77. Ayat tersebut mengatakan ad-daaral aakhirah, menurut tafsir al-Maraghi kata tersebut diartikan sebagai pahala dari Allah dengan menafkahkan harta dengan mengharap ridha-Nya dengan sebaik-baik tasharruf dalam jual beli dan berusaha. ${ }^{32}$ Sedangkan dalam tafsir al-Qaasimi, dikatakan bahwa kata ad-daaral aakhirah dalam ayat ini diartikan sebagai pekerjaan yang bernilai kebaikan dari pekerjaan yang wajib dan sunah yang menjadi tambahan pahala di akhirat kelak. ${ }^{33}$

Berdasarkan penjelasan mengenai ayat yang berkaitan dengan perintah Allah kepada manusia untuk tidak melupakan bagian dari usaha dunia, maka dengan ayat itulah secara kontekstual Allah Swt memerintahkan untuk giat bekerja, bekerja keras untuk mencari kekayaan di dunia namun tidak semata hanya untuk menimbun kekayaan yang diperoleh itu, akan tetapi tujuannya adalah untuk mencari keridhaan Allah sebagai bekal untuk kehidupan akhirat kelak.

Selanjutnya, maksudnya carilah dari apa yang diberikan oleh Allah kepadamu untuk kebahagiaan akhirat yaitu melalui pahala yang dihasilkan oleh harta yang digunakan dalam ketaatan kepada Allah. Kemudian, maksudnya mengambil bagian dari dunia sesuatu yang

\footnotetext{
${ }^{31}$ Suryana, Kapita Selekta Evolusi Pemikiran Kebijakan Ketahanan Pangan (Yogyakarta: BPFE, 2003).

${ }^{32}$ Ahmad Musthofa Al-Maraghi, Tafsiirul Maraghi Juz 20 (Darul Ulum, 1946).

${ }^{33}$ Muhammad Jamaluddin Al-Qaasimi, Tafsiirul Qaasimi Juz 13 (Daarul Fikr: Beirut, 1914).
} 
mencukupi sesuai kebutuhan operasional dalam hidup atau berbuat dan bekerja di dalam dunia sebagai sarana untuk mendapatkan kebahagiaan di akhirat.

Dengan demikian, seorang wirausahawan harus seimbang antara menjalani aktivitas usahanya dan ibadah kepada Allah Swt. Hal tersebut dapat dicerminkan dalam Alquran surat al-Jumu'ah ayat 9-11, yang berbunyi:

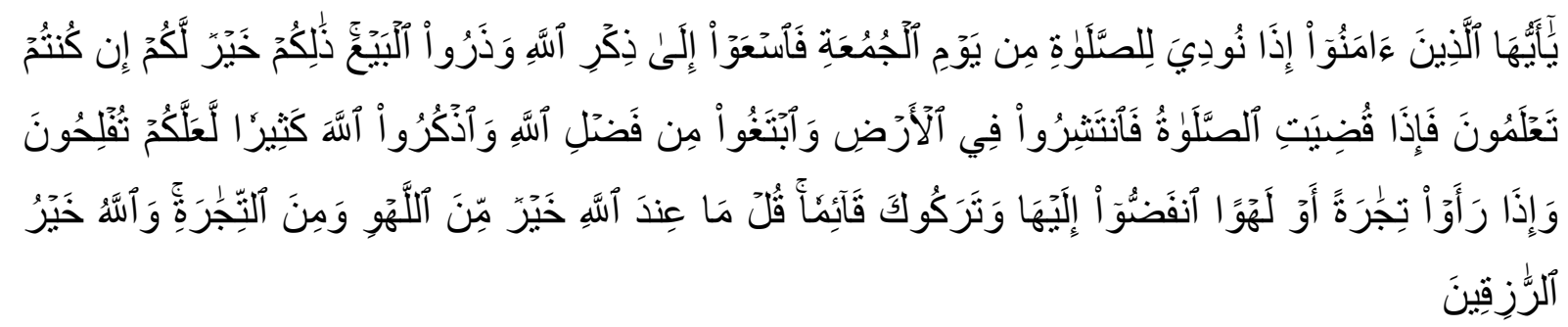

Hai orang-orang beriman, apabila diseru untuk menunaikan shalat Jum'at, maka bersegeralah kamu kepada mengingat Allah dan tinggalkanlah jual beli. Yang demikian itu lebih baik bagimu jika kamu mengetahui. Apabila telah ditunaikan shalat, maka bertebaranlah kamu di muka bumi; dan carilah karunia Allah dan ingatlah Allah banyak-banyak supaya kamu beruntung. Dan apabila mereka melihat perniagaan atau permainan, mereka bubar untuk menuju kepadanya dan mereka tinggalkan kamu sedang berdiri (berkhotbah). Katakanlah: "Apa yang di sisi Allah lebih baik daripada permainan dan perniagaan", dan Allah Sebaik-baik Pemberi rezeki.

Ayat tersebut menyatakan bagi orang-orang yang beriman, apabila diseru yakni dikumandangkan adzan oleh siapapun untuk sholat dzhuhur hari jum'at, maka bersegeralah kuatkan tekad dan langkah, jangan bermalas-malasan apabila mengabaikannya, untuk menuju dzikrullah menghadiri sholat dan khutbah jum'at, dan tinggalkanlah jual beli yakni segala macam interaksi dalam bentuk dan kepentingan apapun bahkan semua yang dapat mengurangi perhatian terhadap upacara jum'at. Untuk menghilangkan kesan bahwa perintah ini adalah sehari penuh, sebagaimana yang diwajibkan kepada orang Yahudi pada hari sabtu, maka dilanjutkan ayat setelahnya yang mengandung arti: lalu apabila telah ditunaikan sholat, maka bertebaranlah dimuka bumi dan carilah sebagian dari karunia Allah dan ingatlah Allah banyak-banyak supaya kamu beruntung. ${ }^{34}$

Sangat indah, bahwa ayat-ayat Alquran juga memiliki perhatian terhadap keberlangsungan ekonomi manusia. Setelah melaksanakan sholat jumat umat Islam tidak diperintah untuk bermalas-malasan akan tetapi umat Islam diperintah untuk mencari rahmat Allah dengan cara bertebaran di muka bumi ini. Allah Swt mengizinkan untuk bekerja dan berusaha mencari rizki dunia selesai melaksanakan sholat, sebagaimana firman-Nya yang menganjurkan seorang muslim tidak boleh bermalas-malasan dalam mencari rizki untuk

\footnotetext{
${ }^{34}$ Quraish Shihab, Tafsir Al-Misbah Juz 4 (Jakarta: Lentera Hati. 2002).
} 
memenuhui kabutuhan hidupnya, karena perintah agar selesei sholat bertebaran di muka bumi mencari rizki yang diungkapkan dalam bentuk amr atau perintah, mengandung arti segera, sebagaimana hal itu dibahas luas dalam ilmu ushul fiqh. kecuali memang waktu untuk istirahat, dan waktu istirahat dipakai sekalian untuk sholat. maka selesei sholat memang beristirahat dan memulihkan tenaga untuk agar bersemamgat dalam bekerja di waktu berikutnya.

Selanjutnya, dalam hadis dijelaskan tentang motivasi berwirausaha, Nabi Muhammad Saw sendiri telah menyatakan, bahwa 9 dari 10 pintu rezeki adalah melalui pintu berdagang. Dengan kata lain, melalui jalan perdagangan inilah, pintu-pintu rezeki akan dapat dibuka, sehingga karunia Allah Swt terpancar daripadananya. ${ }^{35}$

Dari Ibnu Umar ra mengatakan: Rasulullah saw Mengambil pundak saya dan mengatakan: Jadilah di dunia seperti orang asing atau musafir, dan Ibnu Umar ra mengatakan: Jika anda pada waktu sore jangan menunggu pagi hari, dan jika Anda pada pagi hari jangan menunggu waktu sore, dan gunakanlah waktu sehat Anda sebelum waktu sakit Anda dan gunakan waktu hidup Anda untuk kematianmu (HR. Bukhari). ${ }^{36}$

Hadis lain yang bersumber dari ibnu abbas ra. dan dari ibnu umar ra. yang berbunyi:

Nabi Saw bersabda: Mencari rizki yang halal adalah jihad (perjuangan). ${ }^{37}$ (HR. Qudlo'i dan Abi Na'im)

Hadis lain yang bersumber dari anas ra. yang berbunyi:

Nabi Saw bersabda: Barang siapa yang tidur malam kelelahan dari mencari penghidupan bagi anak-anaknya maka dia bermalam dalam keadaan diampuni dosanya. Dan dalam riwayat lain : Barang siapa yang bermalam kelelahan dari mencari rizki yang halal maka bermalam dalam keadaan diampuni dosanya (HR. Ibnu Asakir) ${ }^{38}$

Hadis lain yang bersumber dari Miqdam Ibnu Ma'dikarib ra. yang berbunyi:

Nabi Saw bersabda: Tidak ada seseorang yang makan makanan itu lebih baik dari pada makam dari hasil karya tangannya sendiri, dan bahwa Nabi Daud as. selalu makan dari hasil karya tangannya sendiri. ${ }^{39}$ (HR Bukhari)

\section{Kesimpulan}

Dari paparan di atas, bahwa motivasi dalam wirausaha memegang peran penting dalam keberlangsungan aktivitas wirausaha dan dapat memberikan manfaat bagi lingkungan sekitar. Berdasarkan analisis dari hasil penelitian yang menggunkan metode penelitian kualitatif dan pendekatan penelitian kepustakaan (library research), maka dapat disimpulkan sebagai berikut:

\footnotetext{
35 Viethzal Rivai, Islamic Business and Economic Ethics (Jakarta: PT Bumi Aksara, 2012).

${ }^{36}$ Ibnu Hajar al-Asqalani, Fathu al-Bari Juz 10 (al-Qahirah: Daaru al-Bayan Li at-Turats, 1987).

37 'Alauddin Ali Ibnu Khisamuddin al-Hindi al-Burhanafuri, Kanzu al-ummal (Beirut: Muassasah ar-Risalah, 1981).

38 'Alauddin Ali Ibnu Khisamuddin al-Hindi al-Burhanafuri, Kanzu al-ummal (Beirut: Muassasah ar-Risalah, 1981).

${ }^{39}$ Imam an-Nawawi, Riyadhu ash-Sholihin (Jeddah: Daaru al-Qiblah Li ats-Tsaqafah al-Islamiyyah, 1990).
} 
1. Pandangan Alquran tentang motivasi wirausaha dapat ditemukan pada teks Alquran surat al-Jumuah ayat 10, ash-Shaf ayat 10-11 dan al-Qashash ayat 77

2. Pandangan hadis tentang motivasi wirausaha dapat ditemukan pada teks hadis yang diriwayatkan oleh Imam al-Bukhari yang bersumber dari Miqdam Ibnu Ma'dikarib ra. yang berbunyi: Nabi Saw bersabda: Tidak ada seseorang yang makan makanan itu lebih baik dari pada makam dari hasil karya tangannya sendiri, dan bahwa Nabi Daud as. selalu makan dari hasil karya tangannya sendiri dan dapat ditemukan pada teks hadis yang diriwayatkan oleh Ibnu Asakir yang bersumber dari anas ra. yang berbunyi: Nabi Saw bersabda: Barang siapa yang tidur malam kelelahan dari mencari penghidupan bagi anak-anaknya maka dia bermalam dalam keadaan diampuni dosanya. Dan dalam riwayat lain : Barang siapa yang bermalam kelelahan dari mencari rizki yang halal maka bermalam dalam keadaan diampuni dosanya.

3. Pandangan tentang motivasi seorang wirausaha yakni perintah untuk bertebaran di muka bumi bukan diam ditempat, kemudian perintah mencari karunia Allah dan banyak mengingatlah Allah. Selain itu, seorang wirausaha dituntut untuk saling membantu atau tolong menolong dalam kebaikan dan tidak memperkaya diri agar seimbang kebutuhan antara dunia dan akhirat.

\section{Daftar Pustaka}

Abdullah, M. Ma'ruf. Wirausaha Berbasis Syariah. Yogyakarta: CV. Aswaja Pressindo, 2011. al-Asqalani, Ibnu Hajar. Fathu al-Bari Juz 10. al-Qahirah: Daaru al-Bayan Li at-Turats, 1987. al-Burhanafuri, 'Alauddin Ali Ibnu Khisamuddin al-Hindi. Kanzu al-Ummal. Beirut: Muassasah ar-Risalah, 1981.

al-Mubarakfury, Syekh Shafiyyur Rahman. Sirah Nabawiyah. Jakarta: Pustaka al-Kautsar, 2000.

al-Qaasimi, Muhammad Jamaluddin. Tafsiirul Qaasimi Juz 13. Daarul Fikr: Beirut, 1914.

Amri, Proses Pembelajaran Kreatif dan Inovatif dalam Kelas. Jakarta: PT Prestasi Pustakaraya, 2010.

an-Nawawi, Imam. Riyadhu ash-Sholihin. Jeddah: Daaru al-Qiblah Li ats-Tsaqafah alIslamiyyah, 1990

Anwar, Muhammad. Pengantar Kewirausahaan, Teori dan Aplikasi. Jakarta: Prenada, 2014. Baum \& Baron, The Psychology of Entrepreneurship. New Jersey: Lawrence Erlbaum Associates, 2007.

Berba, Michele. Membangun Kecerdasan Moral. Jakarta: Gramedia Pustaka Utama, 2008. Ciputra, Quantum Leap Entrepreneurship. Jakarta: Elex Media Komputindo, 2009.

Hamalik, Oemar. Psikologi Belajar dan Mengajar. Bandung: Sinar Baru Algensindo, 2004. Irawan, Aguk. Penakluk Badai. Jakarta: Republika, 2012.

Jusmaliani, Bisnis Berbasis Syariah. Jakarta: Bumi Aksara, 2008.

Jusmaliani. Bisnis Berbasis Syariah. Jakarta: Bumi Aksara, 2008.

Kasmir, Kewirausahaan. Jakarta: PT Raja Grafindo Persada, 2008. 
Ma'luf, Louis. Al-Munjid. Beirut: Dar al-Masyriq, 1987.

Mahfoedz, Mahmud. Kewirausahaan, Metode, Manajemen dan Implementasi. Yogyakarta: BPFE, 2006.

Prawira, Purwa Atmaja. Psikologi Pendidikan dalam Perspektif Baru. Yogyakarta: Ar-Ruzz Media, 2014.

Rivai, Viethzal. Islamic Business And Economic Ethics. Jakarta: PT Bumi Aksara, 2012.

Saiman, Leonardus. Kewirausahaan: Teori, Praktik, dan Kasus-Kasus. Jakarta: Salemba Empat, 2009.

Shihab, Quraish. Berbisnis Dengan Allah. Jakarta: Lentera Hati, 2008.

Shihab, Quraish. Tafsir Al-Misbah Juz 4. Jakarta: Lentera Hati, 2002.

Siswanto, Agus. The Power of Islamic Entrpreneurship. Jakarta: Amzah, 2016.

Sukmadinata, Nana Syaodih. Landasan Psikologi Proses Pendidikan. Bandung: PT Remaja Rosdakarya, 2007.

Suryana, Yunus dan Kartib Bayu. Kewirausahaan: Pendekatan Karakteristrik Wirausaha Sukses. Jakarta: Kencana, 2011.

Tarmudji, Tarsis. Prinsip-Prinsip Wirausaha. Yogyakarta: Liberty, 2003.

Terry, George. Prinsip-Prinsip Manajemen. Jakarta: Bumi Aksara, 1996.

Thobrani, Super Sukses Muhammad. Yogyakarta: Cakrawala, 2011.

Uno, Hamzah B. Teori Motivasi dan Pengukurannya. Jakarta: Bumi Aksara, 2008.

Zuhaily, Wahbah. Al-Fiqh al-Islamiy wa Adillatuh Juz IV. Damasyiq: Dar al-Fikr, 1989. 